\title{
School Counselors' Response to School Shootings: Framework of Recommendations
}

\author{
Carleton H. Brown, PhD \\ University of Texas at El Paso, El Paso, Texas, United States \\ (iD https://orcid.org/o0oo-0002-6239-6165
}

Contact: $\underline{\text { chbrown } @ u t e p . e d u}$

\section{Abstract}

Despite the many expectations of school counselors in responding effectively to crisis situations, there is a lack of research and comprehensive standards that address best practices for school counselors in terms of preparing for and responding to a school shooting. Using federal guidelines and crisis literature, including studies focused on school counselors' lived experiences of a school shooting, the author offers a researchinformed theoretical framework of recommendations at different phases of a school shooting. The framework of recommendations points out probable hindrances to school counselors' decision making. School counselors' awareness of these impediments before experiencing each phase of such a crisis would be of benefit to them. School counselors may also use the framework of recommendations to help them assess their developmental needs in relation to preparing for and responding to a school shooting crisis.

Keywords: school shooting; crisis preparation; crisis response

Date Submitted: January 30, 2020 | Date Published: August 24, 2020

\section{Recommended Citation}

Brown, C. H. (2020). School counselors' response to school shootings: Framework of recommendations. Journal of Educational Research and Practice, 10, 274-298. https://doi.org/10.5590/JERAP.2020.10.1.18

\section{Problem}

Since the early 1980s, youth aggression in schools has continued to increase (McAdams, 2002). This aggression manifested itself in dramatic fashion during the mid- to late-1990s when a series of school shootings shocked the nation (Langman, 2009). School shootings have continued since the 1990s, and Americans' perceptions of school have changed from that of a place of safety to a place of potential harm (Rocque, 2012). The United States Department of Justice and the Federal Bureau of Investigation (FBI) examined up to 160 shooting situations that occurred between 2000 and 2013 and concluded that educational settings were the second most likely sites to experience an active shooter incident (Blair \& Schweit, 2014). Although researchers have given much attention to prevention measures and strategies, shootings on school campuses continue (Ahmed \& Walker, 2018). 
Brown, 2020

\section{Review of the Literature}

\section{Prevention Is Not Enough}

Since the 1990s, legislatures and administrators have recognized that school shootings differ from other crises. Consequently, much attention has been directed at the prevention of school shootings, and several preventive measures have been developed, including the Gun-Free Zones Act passed by Congress in 1994 (Fox \& Burstein, 2010). Despite being an encouraging attempt at curbing gun violence in school areas, the GunFree Zone Act prompted school administrators to develop zero-tolerance policies that unfortunately have proven to be ineffective for preventing gun violence (Heaviside et al., 1998; Skiba, 2008; Skiba \& Peterson, 1999). Administrators have also implemented low-level security measures, including requiring students to wear ID badges, installing security cameras, conducting drug testing, and using metal detectors (Dinkes et al., 2009). However, none of these measures has proven effective for preventing school shootings (Langman, 2009).

Administrators have also added the presence of School Resource Officers (SROs), employed law enforcement officers who work in collaboration with school(s) (National Association of School Resource Officers, n.d.) to prevent gun violence, yet school shootings continue despite the presence of SROs. For example, the Washoe County School District in Spark, Nevada, spent millions on security by erecting fences, providing training, and hiring SROs; nonetheless, in 2013, a student murdered a teacher and injured others before committing suicide at a middle school within the district (Bellisle, 2013). Moreover, in 2018, although a distraught teenager notified the FBI of his premeditated plans several months before the incident, the student opened fire at his school, killing 17 people and injuring 14 (Chuck et al., 2018). Overall, the research addressing preventive policies and security procedures suggests that continued efforts and concern for safety on school campuses in the United States are still warranted.

\section{Need for School Counselors' School Shooting Framework of Recommendations}

Although research has identified school shootings as atypical crises (Newman et al., 2004; Langman, 2009), preparation for and responses to school shootings are often placed in the same category as preparation for and responses to crisis situations in general. For example, the American School Counselor Association (ASCA) has addressed the critical nature of school counselors in crisis situations in their Safe Schools and Crisis Response statement (adopted in 2000; ASCA, 2013). The statement was updated in 2013 and cited Fein's (2003) and Fein et al.'s (2008) research regarding school counselors' lived experiences of school shootings throughout the document. As an example, ASCA (2013), in line with Fein (2003), makes it clear that school counselors are often placed in situations that require them to secure the safety and welfare of their building's population in times of crisis. ASCA (2013) promotes the idea that school counselors ought to assist distraught crisis survivors and take on leadership duties after a violent crisis (supported by Fein et al., 2008). ASCA's (2018) position statement on gun violence encourages school counselors to use their skills to support a comprehensive approach to school safety. Although ASCA's 2013 and 2018 position statements concerning gun violence, safety, and crisis are supported by research that examines school counselors' lived experiences of school shootings, the statement still falls short of providing a comprehensive framework of researchinformed recommendations for school counselors when faced with school shootings (ASCA 2013; 2018). This is problematic not only because school shootings differ from most other crisis situations, but also because school counselors have a legal and ethical mandate to make all reasonable attempts to curb violence in schools (Hermann \& Finn, 2002). One of the school counselors' professional competencies states:

An effective school counselor is able to... understand what defines a crisis, the appropriate response and a variety of intervention strategies to meet the needs of the individual, group, or school community before, during, and after crisis response. (ASCA, 2012, p. 156) 
The professional competency makes it clear that school counselors are expected to respond appropriately before, during and after a school shooting (ASCA, 2019); therefore, a more comprehensive framework of research-informed recommendations pertaining to school shootings would help school counselors meet this ASCA competency requirement, in addition to limiting the potential for inefficient responses and outcomes for client survivors.

\section{Current Models}

Although models exist that focus on an entire school's response to violent crises, few focus on counselors. Two models that stand out in the literature are the Preparation, Action, Recovery (PAR) model and the PREPaRE model (Prevent and prepare; Reaffirm; Evaluate; Provide interventions and Respond). McAdams and Keener (2008) examined national and state expectations regarding professional counselors' responses to crisis situations. The researchers found expectations for counselors in crisis situations to be both inconsistent and less than comprehensive. Using phase progression research from the mental health field, the authors created a crisis framework entitled PAR, which addresses counselors' responses to client suicide and client violence. Although useful, the framework is not specific to school counselors' responses to school shootings.

The authors of the PREPaRE model included Crisis Prevention and Intervention and working groups associated with the National Association of School Psychologists (NASP). The model highlights how schoolbased mental health providers work with school crisis teams when addressing crisis situations (Brock et al., 2009, p. viii). The model is influenced by recommendations from the U.S. Departments of Education and Homeland Security. Utilizing the idea of phase progression, the authors describe how school-based mental health providers may assist with the prevention of and preparedness for psychological trauma, reaffirming physical health and perceptions of security and safety, evaluating the risk of psychological trauma, providing interventions, and responding to psychological needs, as well as examining the effectiveness of crisis prevention and intervention. Although beneficial, the model is not specific to school counselors' responses to school shootings.

\section{Development of the School Counselor Response to School Shootings Framework of Recommendations (SCRSS-FR)}

\section{Theoretical Foundation}

The theoretical foundation of this conceptual framework of research-informed recommendations is influenced by school counselors' lived experiences and federal guidelines and comprises two theories: 1) situational crisis and 2) phase progression. According to James (2008), a situational crisis occurs randomly and without warning; therefore, it aligns with the applied crisis theory. Brammer (1979) explained that "situational crises are associated with severe loss" (p. 104). Bockler et al. (2013) analyzed various national and international definitions and classifications of school shooting crises and determined that rampage school shootings were committed by shooters who selected victims randomly with the intent of causing multiple or severe losses. This notion aligns with the situational crisis theory.

The U.S. Department of Education, Office of Elementary and Secondary Education, and Office of Safe and Healthy Students (2013), as well as the U.S. Department of Justice's Bureau of Justice Assistance and the International Association of Chiefs of Police (2012), determined that, as major crises on school campuses are situational, schools should have comprehensive crisis plans and procedures that include the roles of important stakeholders. These entities promote a comprehensive theoretical approach that suggests that crises unfold sequentially and therefore include planning for before, during, and after violent crises. McAdams and Keener (2008) argued that this idea of "sequential progression toward crisis" can be used to work with clients suffering mental health crisis as the result of violence and termed the theory "phase progression in 
mental health crisis" (p. 389). The authors further explained that, by conceptualizing crises in phases, counselors may better prepare and coordinate specific interventions and "structured support for survivors. Lastly, the authors recommended the following phases: pre-crisis preparation, pre-crisis awareness, in-crisis protocol, in-crisis awareness, post-crisis recovery, and post-crisis awareness. These phases make up the skeleton of the SCRSS-FR.

\section{Previous Research: School Counselors}

School counselors offer critical assistance to their buildings' populations as they experience crises or respond to emergency situations (ASCA, 2019), but few researchers have examined school counselors' lived experiences of school shootings (Fein et al., 2008; Daniels, et al., 2007a; Brown, 2015). The author conducted an extensive search to identify studies dedicated to reporting school counselors' lived experiences of school shootings and found three studies and several additional reports. For instance, in 2001, Fein completed a study that included interviewing formal leaders (such as superintendents and principals) who had experience of school shootings. Based on the 2001 study, Fein et al. (2008) reported several ways in which school counselors responded to school shootings and summarized these reports as four lessons for school counselors:

- Be prepared to lead,

- serving two organizations creates role conflict,

- employ subtle counseling, and

- $\quad$ minister to thyself.

Another example is Daniels et al.'s 2007a study that included interviewing a school counselor who had experienced a hostage situation. From the interview, Daniels et al. gleaned important recommendations for school counselors, such as developing trusting relationships with students, seeking crisis training, and working as a team to create a safe and trusting atmosphere. In a third example in 2019, Brown interviewed school counselors who had survived a school shooting (2019). The primary goal of the study was to explore the school counselors' experiences. The results of the study included but were not limited to important actions and decisions made by school counselors as they attempted to secure physical and emotional support for others.

Additional examples in the literature included but were not limited to individuals who had experienced or witnessed school counselors' roles in surviving a school shooting (Fein, 2001; Brown, 2015; Brown, 2017; Kennedy-Paine, 2018; Poland, 2018), as well as school counselors' self-reports. For example, Austin (2003) served as a school counselor assisting the recovery efforts in the immediate aftermath of the 1999 Columbine High School shooting rampage. Austin provided a self-report of her experience that included informal interviews she conducted with her fellow school counselors who experienced the tragedy. She summarized three critical points for school counselors:

- Counselors can easily become overloaded after such a tragedy,

- relationships are critical throughout such an event, and

- $\quad$ staff should be encouraged to seek counseling after such a crisis.

While each of the findings of these studies and reports is helpful individually in identifying ways in which school counselors have responded to gun violence, each finding in isolation falls short of being either 
conclusive or comprehensive, thus making clear the need for a school counselors' framework of recommendations in the event of a school shooting.

\section{The SCRSS-FR Components: Research and Literature}

The SCRSS-FR includes six stages, each of which has corresponding components. These components have been shaped by federal guidelines, the relevant literature, and previous studies. A discussion of the federal guidelines, research, and relevant literature that supports the framework is presented.

\section{Phase One: Pre-Crisis Preparation (PCP)}

Predicting a school shooting is difficult (O’Toole, 1999; National Threat Assessment, 2018; Van Dreal, 2011). For counselors, preparing for crisis situations is a best practice (ASCA, 2018, 2019; James, 2008). The precrisis phase highlights effective steps in which school counselors unknowingly engaged or learned as they prepared for a school shooting. The primary steps include (a) using appropriate assessments, (b) having a defined role on a school crisis team, and (c) building quality relationships.

\section{Using appropriate assessments}

ASCA's 2012 school counselor competencies specify that a school counselor "knows and understand[s]... assessment techniques" (ASCA 2012, p. 154). Researchers have found that assessments centered solely on the personal attributes of potential assailants do not predict school shooters effectively (O'Toole, 1999; Van Dreal, 2011). More promising research supports a holistic, team, and integrated-systems approach (Barton, 2009; Fein et al., 2004; National Threat Assessment, 2018; Van Dreal, 2011; Verlinden et al., 2000).

Specifically, a holistic approach refers to the examination of factors beyond individual characteristics. Common factors considered by researchers included individual factors such as personality traits and behaviors, school and peer characteristics, family factors or dynamics, and social and environmental factors (Verlinden et al., 2000; O’Toole, 1999).

Next, a team approach collaboratively identifies factors to assess at different levels. For example, a school team representing various views performs a level-one assessment by examining certain factors; however, if a more comprehensive assessment is required, a community-based team conducts a second level of assessment that may include more factors (Van Dreal, 2011). The most important common factor to assess is the situation (Fein et al., 2004; Newman et al., 2004; Van Dreal; Verlinden et al., 2000).

Finally, Fein et al. (2004) promoted a systems approach. They suggested that, when considering factors such as the circumstances or situation, the central guiding question to investigate is "whether a student poses a threat, not whether the student has made a threat" (p. 29). Van Dreal (2011) suggested that decisions based on assessments should include "indications of risk, the escalation of that risk, and the protective supports and strategies needed to decrease the risk" (p. 5). Employing up-to-date, research-based, and effective assessment approaches is critical for school counselors.

\section{School crisis team member}

Research indicates that stakeholders-including teachers, administrators, parents, and students-consider school counselors to be integral both during and after school shootings (Brown, 2017; Fein, 2001; Damiani, 2011). Counselors were often given administrative responsibilities and made crucial decisions throughout such crises (Fein et al., 2008). Nonetheless, few school counselors had been designated to school crisis teams prior to school shootings taking place. The architects of federal guidelines regarding the development of school crisis plans for school crisis teams admonish that school counselors are critical in the stages of prevention, response to, and recovery from a school shooting (U.S. Department of Education, 2007; U.S. 
Department of Education et al., 2013; U.S. Department of Justice et al., 2012). Assigning defined roles to school counselors who form part of school crisis teams would assist schools in preparing for a school shooting. The NASP (2018) acknowledged that school counselors would be key personnel to include in a crisis response leadership team. Barton (2009) also encouraged schools to include mental health specialists on the team; the author stated that student education was critical and should include "conflict resolution educational programming" (p. 42). As part of a school crisis team, school counselors may advocate to team members to acknowledge that this type of programming occurs within a comprehensive school counseling program (ASCA, 2016b; 2018).

\section{Building quality relationships}

The relationships school counselors have developed with the community, peers, students, parents, and other faculty and staff have proved to be beneficial throughout school shootings (Austin, 2003; Daniels et al., 2007a; Mears, 2012). Relationships are essential for providing collaborative team efforts in responding (National Threat Assessment, 2018; Kennedy-Pain, 2018; Poland, 2018), accounting for students, connecting students with parents, and helping to ensure physical and emotional support for those who experienced or were affected by such a crisis (Brown, 2019; Cowan et al., 2013; NASP, 2018; Kennedy-Pain, 2018). Barton (2009) emphasized the importance of bridging gaps among parents and teachers concerning school safety. ASCA (n.d.) affirmed that it was critical to rebuild and reaffirm attachments both pre- and post-crisis. Methods used by school counselors to build quality relationships include checking in with students periodically, advocating for students and parents, assisting with personal crises, and establishing and participating in programs that encourage communication among stakeholders (ASCA, 2018). These programs may include mentorship programs, advisory programs, and parent education events. Pepper, London, Dishman, and Lewis (2010) clarified that crisis survivors who created trusting relationships and resilient cultures prior to the disruptive event were more likely to have a better response to a crisis and to return to normal more quickly.

\section{Phase Two: Pre-Crisis Awareness (PCA)}

The primary focus of this section includes crisis training, crisis supervision or leadership, and school-based counselors. Because school counselors have an ethical and legal mandate "to act reasonably to prevent school violence" (Hermann \& Finn, 2002, para. 24), it is reasonable for school counselors to recognize their limitations with regard to technical competence and support in terms of training for crisis situations, providing supervision, and accessing assistance from outside counselors.

\section{Periodic crisis training}

Mears (2012), Pepper et al. (2010), the U.S. Department of Education (2007), and the U.S. Department of Justice et al. (2012) emphasized the importance of crisis drills and training for school personnel. Barton (2009) emphasized the importance of the of professional development or continuous crisis training. According to the NASP (2018), school districts should ensure appropriate training for mental health professionals. If school counselors are indeed essential members in responding to crises (U.S. Department of Education, 2007; ASCA, 2012), they need training to address a range of crises (Brock et al., 2016). Damiani (2011) quoted Pitcher and Poland (1992) as saying that the "lack of preparation... with crisis situations adds to... risk of burnout, stress and depression" (p. 15). School counselors need to stay current with regard to crisis training not only for their own personal health, but also to respond more effectively "before, during, and after" a crisis to "lessen the impact on life" (U.S. Department of Education, 2007, p. 21).

\section{School counselor supervisor}

School counselors need not only be part of the safety team (Barton, 2009), but also considered key members of crisis response mental health professionals (NASP, 2018). It would be beneficial for these mental health professionals to have a crisis response team leader (U.S. Department of Justice et al., 2012). This leader may be a district counselor or a supervisor whose role would be to help manage school members' emotional and 
intervention needs. (U.S. Department of Education, 2007). Because school counselors will accept leadership roles and assume decision-making responsibilities beyond their normal duties in a crisis (D'Andrea, 2004; Fein et al., 2008), authors of the Guide for Preventing and Responding to School Violence insist that school counselors must remain in close contact with the counseling leader assigned to manage and provide guidance in a crisis (U.S. Department of Justice et al., 2012). According to Kennedy-Paine (2018), after a school shooting the mental health crisis team leader is required to conduct "on-the-spot modification of procedures we'd used in dozens of crisis interventions over the previous seven years" (p. 203). The mental health team has been beneficial in helping those who have survived school violence (U.S. Department of Health and Human Services, 2004).

\section{Counselors' communication process}

School counselors refer students with chronic or extremely serious issues to school-based agencies or other counselors (ASCA, 2019; Baker \& Gerler, 2008; Newman et al., 2004). However, school counselors who had experienced a school shooting observed that communication between school-based therapists and school counselors about shared concerns regarding particular students were rare (Fox et al., 2003; Brown, 2015). It is important to have established communication among providers throughout a traumatic event (Damiani, 2011). Mears (2012) mentioned that trusting relationships and good communication assist with establishing connections between students and mental health agencies, particularly during times of tragedy (p. 9). Barton (2009) made clear the importance of a "confidential reporting system" as part of a school safety plan (p. 41). ASCA (2019) confirmed the idea that effective school counselors seek the help of other professionals in the event of a potential crisis situation.

\section{Phase Three: In-Crisis Protocol (ICP)}

School counselors who experience school shootings need to be prepared to employ methods to help deescalate and offer safety to crisis survivors during the event (Bockler et al., 2013). It would be beneficial to understand these methods prior to a school shooting. Practices may include developing protocols for schoolattending family members, fulfilling expected duties while remaining flexible, and using various de-stressing strategies to help others.

\section{Family members' protocol}

School counselors working with families and who are concerned about their own school-attending family members would benefit from having a plan for communication and pick-up (Erbacher \& Reeves, 2018; U.S. Department of Homeland Security, 2019). The U.S. Department of Education et al. (2013) encouraged the development of a Family Reunification Annex (FRA). The FRA is an attempt to pre-plan ways to reunite students and their families while being able to modify plans as needed. Considerations when developing such a plan include the role of the families or guardians, the identification of authorized adults, facilitating communication, decreasing confusion, and anticipating technology barriers as well as language access barriers. The reunification process may begin during and/or immediately after a tragedy. Another suggestion for school counselors is to have their school-aged family members establish a calling tree to acknowledge they are experiencing a crisis and to arrange for pick-up. Regardless of whether a calling tree or a complete FRA is used, the key is to have a protocol for loved ones to ensure their personal safety, allay the school counselor's personal anxiety, and reunite families during a school shooting (U.S. Department of Education, 2007). Of course, such a plan depends on the age or grade of the child (Brock \& Jimerson, 2004); for example, a high school student may have his or her own transport, thus making communication a more pressing issue than pick-up.

\section{Role expectations}

It is important for school counselors to have defined roles when a crisis occurs (U.S. Department of Education, 2007). The U.S. Department of Justice et al. (2012) state that the most important role of responding personnel in schools is to get students to safety. Not only would it be beneficial for school counselors to assist in providing students with physical safety, but also to help students with their emotional 
and psychological needs (Pepper et al., 2010). According to ASCA (2019), effective school counselors understand their role and the expectations of their program in a school crisis plan. Schools and their counselors would benefit from having clearly defined responsibilities and expectations while allowing for some flexibility in the actions of school counselors during a school shooting.

\section{De-stressing techniques}

School counselors would benefit from having de-stressing techniques at their disposal during a school shooting crisis. Techniques suggested by Nader and Nader (2012) for use during crises such as school shootings include deep breathing, mental imagery, and muscle relaxation techniques. Pepper et al. (2010) described ways to calm students such as covering windows, singing, and reading to the children. Brown (2019) stated that techniques used by school counselors with students during a school shooting included hugging or physical touch, reaffirming, informing, and encouraging. Brock et al. (2004) encouraged the use of anxiety management and stress-inoculation coping techniques. ASCA (2019) noted that school counselors responded effectively by using a range of appropriate intervention strategies to assist others during a crisis.

\section{Phase Four: In-Crisis Awareness (ICA)}

School counselors must recognize their professional limitations if they are to succeed in assisting others during a crisis (ASCA, 2016a). Therefore, it stands to reason that school counselors who experience a school shooting are more effective if they are able to assess their professional skills during such an incident (Brock et al., 2016). Areas of significance for school counselors during school shootings include employing self-care strategies from their professional toolkit and recognizing the extent of their ability to help others.

\section{Self-care}

School counselors experienced a range of emotions during school shootings and reported feeling petrified, scared, taken aback, worried, lonely, and overwhelmed (Austin, 2003; Brown, 2019; Fein, 2003). School counselors were also aware of possible secondary trauma arising from having assisted trauma victims (Fein et al., 2008). School counselors who had experienced a school shooting would have benefited from having had access to self-care strategies during the event. School counselors would benefit from increased knowledge of personal trauma (Watkins Van Asselt et al., 2016) and self-care strategies such as pausing to recollect when necessary, listening to one's inner monologue to counteract negative talk and disturbing feelings, and using positive affirmations (Nader \& Nader, 2012).

\section{Professional competency}

According to D' Andrea (2004), counselors are required to take on a leadership position that exceeds the typical role of a counselor when a school crisis occurs. However, Poland (2018) made it clear that there are times when those who take on leadership positions during a crisis recognize and accept their limitations "without judgment or repercussions" (p. 223). A logical conclusion is that school counselors not only assess their professional limitations, but also be open to receiving professional assistance from other school counselors or community professionals when working with individuals who need help during a crisis. Ethically, school counselors work within their personal limits of professional competency and collaborate with outside service providers in the best interests of the population they serve (ASCA, 2016a).

\section{Phase Five: Post-Crisis Recovery (PCR)}

School counselors are expected to assist others after a crisis. School counselors who may experience a school shooting will need to be prepared to assist crisis survivors and help their schools recover from the tragedy (U.S. Department of Justice et al., 2012). Recommendations include the importance of being a trained 
resource, offering readily available resources, working within clearly defined roles and expectations while maintaining flexibility, and practicing relevant strategies and interventions.

\section{Trained resource}

A primary concern for school crisis teams is that students and their mental health needs could vastly outnumber school counselors following a crisis (Newman et al., 2004). This is particularly problematic during attempts to conduct psychological triage. School counselors are expected to meet and assist crisis survivors; therefore, they must be trained to help those suffering from psychological trauma (Mears, 2012). School counselors who are trained to assess psychological risk would benefit not only the crisis team and other mental health workers, but also crisis survivors (Crepeau-Hobson et al., 2012; Crepeau-Hobson \& Summers, 2011). Effective triage assessment models for crisis interventions that school counselors could follow include those advocated by Myer et al. (1992), Myer (2001), and Brock et al. (2016).

\section{Readily available resources}

Additional problems that counselors and other crisis team members encounter is having unqualified assistance from helpers, being overwhelmed, and having limited resources (Fein et al., 2008; Crepeau-Hobson et al., 2012; Jones, 2019). It would be beneficial for counselors to have advance preparation in terms of resources (U.S. Department of Education et al., 2013). For example, having a pre-screened list of community volunteers available would assist by providing prior knowledge of volunteer counselors' or therapists' qualifications, and/or assigning community liaison people to appropriate roles (DeMatthews \& Brown, 2019; Griffin \& Farris, 2010). In addition, in order to assist crisis survivors with comprehending the probability and effects of psychological risk or harm, school counselors could have ready access to and provide a list of educational materials covering the impact of short- and long-term trauma and basic life resource materials to help cope and manage as a result of the crisis (Litz et al., 2002). These efforts may begin the process of helping the school to become a more trauma-informed school (Erbacher \& Reeves, 2018).

\section{Roles and Expectations}

School counselors' responsibilities may vary in the immediate aftermath of school shootings. Primary responsibilities tend to include empathic action, or acknowledging, comforting, and soothing others (Daniels et al., 2007b). However, other duties often include assisting with hotlines, inquiries about missing people, death notification and supporting the grieving (U.S. Department of Health and Human Services, 2004). Such responsibilities and duties may become difficult to prioritize (Brock, et al., 2016; Brown, 2019; Fein et al., 2008). School counselors are a critical resource in crisis recovery (U.S. Department of Education, 2007). Having clear roles, goals, and expectations for school counselors to ensure that their expertise is used efficiently would benefit both schools and crisis managers. However, the unpredictable nature of such tragedies supports giving school counselors some level of flexibility while requiring them to fulfill defined responsibilities.

\section{Strategies and Interventions}

School counselors may use basic skills and various strategies to aid crisis survivors after school shootings. Parker et al. (2006) advocate the use of psychological first aid or immediate assistance with support and resources for survivors exhibiting trauma. Collins and Collins (2005) emphasize the need for individual crisiscounseling sessions to assist with urgent emotional and physical needs. Daniels et al. (2007b) recommended Weinberg's (1990) method of providing counseling for trauma survivors by conducting large group counseling, offering cognitive-behavior groups, psychodynamic groups, and support groups (Daniels et al., 2007b). Daniels et al. (2007b) also admonished the use of another type of group counseling, psychological debriefing, as a commonly used practice for crisis survivors after a violent crisis. Psychological debriefing includes group members receiving information about the crisis response, sharing experiences, and exploring coping strategies; however, the authors also make clear supportive research proving its usefulness is lacking. 
Brock et al. (2016) considered the shortcomings of psychological debriefing identified in empirical research and attempted to address them in developing the PREPaRE Group Crisis Intervention method.

School counselors who have experienced a school shooting have recounted their use of the following strategies and interventions following a crisis: "listening skills, consoling, embodying genuineness and trust, group play therapy, guidance [and character education] lessons, and referrals" (Brown, 2015, p. 155). School counselors have also utilized advanced skills, including family therapy and system principles (Fein et al., 2008). Effective school counselors have an array of strategies and interventions in their professional toolkit to employ after a school shooting.

\section{Phase Six: Post-Crisis Awareness (PoCA)}

School counselors need to recognize and address obstacles to the process of recovering from the crisis. By acknowledging these challenges, school counselors could learn about and improve on the process of assisting others. Critical areas of interest for school counselors in this phase include long-term care for others and personal care or support.

\section{Long-term care}

Researchers have made clear that students, parents, and teachers experienced long-term psychological effects after a school shooting, such as increased stress, post-traumatic distress, mood swings, and social isolation, to name a few (Daniels et al. 2007b; Jones, 2019; Suomalainen et al., 2011). Many crisis survivors tend not to seek counseling or to resist counseling services beyond the immediate aftermath (Lyytinen \& Palonen, 2012; Newman et al., 2004). Therefore, it is critical that schools and school counselors assist survivors of a traumatic event by assessing and continually educating crisis survivors about coping strategies (Dekovic et al., 2008; Gil \& Caspi, 2006; Daniels et al., 2007b), and by providing appropriate referrals, additional counselors, and extended counseling services (Fox et al., 2003; Jones, 2019; U.S. Department of Education, 2007; US Department of Health and Human Services, 2004).

\section{Personal care or support}

School counselors who provide counseling services after a traumatic event are subject to psychological effects such as compassion fatigue, vicarious traumatization, and/or secondary traumatic stress (Meyers \& Cornille, 2002; Lambert \& Lawson, 2013). Kennedy-Paine (2018) cited Bolnick and Brock (2005) as stating that additional reactions may also include "anxiety, difficulty concentrating, helplessness, sleep difficulty, irritability and preoccupation with the event” (Kennedy-Paine, 2018, p. 208). School counselors and other mental health professionals would benefit from engaging in positive, proactive activities after a crisis, such as peer supervision and consultation, professional development and training, peer, school, and family support, self-care activities, and professional counseling (Daniels et al., 2007b; Jordan, 2010; Williams et al., 2012).

The SCRSS-FR was informed by a considerable review of the crisis literature with a specific focus on school counselors, federal guidelines, and theoretical foundations. In addition, five experts were recruited to incorporate their professional input and feedback about the framework of recommendations. Each expert had over 20 years of experience in his or her particular area of expertise. Expert 1 was a school counselor who survived a school shooting, Expert 2 was a district-level school crisis manager, and Expert 3 was a full professor. The professor's primary course of instruction was crisis counseling and the professor had contributed books, book chapters, and several journal articles to the professional literature on crises. Expert 4 was a school counselor district supervisor, and Expert 5 was a school counselor. The experts assisted in refining the framework of recommendations. 


\section{Differences Between Models}

The primary difference between the SCRSS-FR and other models-such as the PAR and PREPaRE models-is that the SCRSS-FR is specific to school counselors and to school shootings. The SCRSS-FR resembles the PAR model more closely in that it uses the same research-informed phase progression (see the Theoretical Foundation section). The distinct differences between the models are evident in the general guideline expectations for each phase. For example, in the PCP phase of the PAR, counselors (not specifically school counselors) are expected to "take general steps to reduce the chances of being blindsided by [a crisis]" (McAdams \& Keener, 2008, p. 390). However, in the PCP phase of the SCRSS-FR, school counselors focus on lessons learned and effective ways school counselors who had lived through a school shooting could have prepared for such a shooting. For a more detailed comparison of the general guideline expectations in the PAR model and those in the SCRSS-FR, see Table 1.

Table 1: Preparation, Action, Recovery (PAR) and School Counselors Response to School Shootings-Framework of Recommendations (SCRSS-FR) Guidelines Comparison

\begin{tabular}{|c|c|c|}
\hline Phases* & PAR General Guidelines & SCRSS-FR General Guidelines \\
\hline PCP & $\begin{array}{l}\text { "Counselors... take general steps to reduce the } \\
\text { chances of being blindsided by [a crisis]" } \\
\text { (p. 390). }\end{array}$ & $\begin{array}{l}\text { Steps taken to reduce the chances of being ill- } \\
\text { prepared to respond to clients' needs during } \\
\text { and after a rampage school shooting. }\end{array}$ \\
\hline PCA & $\begin{array}{l}\text { "Counselors must determine the limits of their } \\
\text { technical and emotional readiness to deal with } \\
\text { various crisis situations" (p. 391). }\end{array}$ & $\begin{array}{l}\text { School counselors recognize their limitations } \\
\text { regarding their "technical and emotional } \\
\text { readiness" in dealing with a rampage school } \\
\text { shooting and their "need for personal and } \\
\text { professional support" in responding to such an } \\
\text { incident (p. 391). }\end{array}$ \\
\hline ICP & $\begin{array}{l}\text { Counselors "efficiently and effectively expedite } \\
\text { de-escalation and safe resolution in a serious } \\
\text { client crisis" (p. 392). }\end{array}$ & $\begin{array}{l}\text { Steps school counselors have taken to "efficiently } \\
\text { expedite de-escalation and safe resolution" } \\
\text { during a rampage school shooting (p. 392). }\end{array}$ \\
\hline ICA & $\begin{array}{l}\text { Counselors are "aware of and able to overcome } \\
\text { potential barriers to handling the event" } \\
\text { (p. } 392 \text { ). }\end{array}$ & $\begin{array}{l}\text { School counselors are "aware of and able to } \\
\text { overcome potential barriers to handling" the } \\
\text { crisis of a rampage school shooting (p. 392). }\end{array}$ \\
\hline PCR & $\begin{array}{l}\text { Counselors help "crisis survivors become able } \\
\text { to manage the debilitating effects of the crisis } \\
\text { sufficiently to resume pre-crisis levels of } \\
\text { functioning" (p. 393) }\end{array}$ & $\begin{array}{l}\text { School counselors help the school system and } \\
\text { "crisis survivors [of a rampage school } \\
\text { shooting] become able to manage the... effects } \\
\text { of the crisis sufficiently to resume pre-crisis } \\
\text { levels of functioning" after the crisis (p. 393). }\end{array}$ \\
\hline PoCA & $\begin{array}{l}\text { "Counselors recognize and work to avoid } \\
\text { pitfalls common to each step in the recovery } \\
\text { process" (p. 394). }\end{array}$ & $\begin{array}{l}\text { School counselors help self and others } \\
\text { recognize and work through challenges to the } \\
\text { recovery process. }\end{array}$ \\
\hline
\end{tabular}

Note: quotations from "Preparation, Action, Recovery: A Conceptual Framework for Counselor Preparation and Response in Client Crises" by C. R. McAdams, III. \& H. J. Keener. (2008). Journal of Counseling \& Development, 86(4), pp. 390-394.

* $\mathrm{PCP}=$ Pre-crisis preparation; PCA = Pre-crisis awareness; ICP = In-crisis protocol; ICA = In-crisis awareness; PCR = Post-crisis recovery; and PoCA = Post-crisis awareness (Brown, 2019). 
Distinct similarities and differences exist between the PREPaRE model and the SCRSS-FR. The two are similar in their understanding of the mental health needs that a crisis might precipitate, such as assessing survivors for psychological trauma, ensuring the emotional and physical safety of survivors, and encouraging mental health professionals to be versed in strategies and interventions to address the psychological needs of survivors (Brock et al., 2009). However, while they are similar, the two models differ in scope: The PREPaRE model takes a more general approach by assisting and encouraging crisis teams to review relevant information concerning how school-based mental health counselors might respond to a violent crisis. By contrast, the SCRSS-FR is based on lessons learned and experiences specific to school counselors' responses to school shootings; thus, it provides information that is directly relevant to the school counseling professional who, in turn, may speak to a crisis team from a knowledgeable, professional point of view regarding how his or her skill set would best be used in response to a crisis. The latter point makes the SCRSS-FR a likely supplement to any crisis plan, regardless of which model the crisis team chooses to follow in the planning process. Lastly, the SCRSS-FR is designed to help support school counselors as school, district, state, and national leaders in preventing and responding to a violent school crisis (ASCA, 2019).

\section{The SCRSS-FR in Practice}

This section describes each phase of the SCRSS-FR, in addition to providing ideas for implementing the framework in practice. This section clarifies the SCRSS-FR alignment with the ASCA National Model, as well as the identification of certain developmental and cultural considerations.

\section{PCP: Description and Activation}

In the pre-crisis phase, there is the recognition that school shootings are situational crises; therefore, they may occur at any time. Bearing in mind the theory that such crises occur in phases and the experiences of school counselors who have lived through such crises, school counselors will benefit from beginning a prevention and preparedness process focused on using appropriate assessments, being a school crisis team member, and building quality relationships.

School counselor supervisors or school counselors may begin to take clear steps in these areas. First, supervisors can request that building school counselors or school counselors identify important stakeholders to serve on a threat assessment team. Such a team may be composed of three to five members with different areas of experience and expertise. The team's primary task is to assess potential threats, devise procedures for various levels of threat, and make recommendations to the school's administration. Second, supervisors can ensure that school counselors are represented on school crisis teams and have defined roles and expectations. Third, school counselors are encouraged to develop and assess methods of building relationships, connectedness, and information sharing. Examples of such methods may include advisory or mentorship programs and workshops for parents. Establishing methods for collecting data and evaluating these methods is highly recommended. For example, school counselors may conduct a school climate survey with a particular emphasis on school connections and safety before and after implementing relationship-building strategies and sharing prevention plans and strategies.

Activating this phase coincides with the school counselor competencies of the ASCA National Model. The school counselor competencies ensure that school counselors are prepared to meet the real-world challenges of the profession. The preparation phase recommends that school counselors advocate for a threat assessment team and a school crisis team. This type of advocacy is aligned with the following ASCA (2019) competencies:

- B-PF 2.c. Explain and/or inform the process for development of policy and procedures at the building, district, state and national levels. 
- B-PF 7.g. Define the role of the school counselor and the school counseling program in the school crisis plan.

- B-SS 6.c. Identify and involve appropriate school and community professionals as well as the family in a crisis situation.

- B-SS 3.e. Respond with appropriate intervention strategies to meet the needs of the individual, group or school community before... crisis response. (pp. 96-99)

Furthermore, the pre-preparation phase encourages school counselors to work to connect with students, their families, and the community. These efforts are aligned with the school counselor mindset competency M 5 . "Effective school counseling is a collaborative process involving school counselors, students, families, teachers, administrators, other school staff and education stakeholders" (p. 6).

School counselors would need to consider the developmental level and culture of their building's population and to bear the unique characteristics of that population in mind. For example, using developmentally appropriate surveys for students is critical for the collection of reliable data. In terms of culture, the overall framework is aligned with the Multicultural Competence of School Counselors (MCSC) framework, which outlines nine distinct areas of competence. The pre-preparation phase is aligned with the competence area "developing school-family-community partnerships" and "understanding cross-cultural interpersonal interactions" (Holcomb-McCoy, 2004, pp. 180-181). The framework recommends that school counselors work in teams with various stakeholders and use feedback to make positive connections with people of all cultures.

\section{Pre-Crisis Awareness: Description and Activation}

In addition to pre-crisis preparedness, it benefits school counselors to assess their own competencies and limitations before the occurrence of a violent situational crisis. The pre-crisis awareness phase emphasizes periodic crisis training, school counselors' supervisors, and communication between school-based and external counselors. School counselors may assess their technical and emotional readiness by reviewing critical areas of their current crisis training; for example, by using the School Counselor Response to Violent Crisis Questionnaire, developed by the author and based on the framework at hand. Among other things, the questionnaire asks respondents to rank their level of confidence about their knowledge of active shooter strategies on a five-point Likert scale. Questions that attract low scores indicate a self-perceived need for more training. For example, if a school counselor were unaware of what was entailed in a situation involving an active shooter, it would be recommended that they participate in active shooter training. School counselor supervisors may consider utilizing the assessment as a tool to begin a discussion of crisis role expectations and training needs. The full questionnaire is freely available from the author on request.

Furthermore, school counselors need to identify and ask particular questions of their school's district counselor supervisor. Such questions would include those pertaining to the school counselor supervisor's expectations of school counselors during a school shooting, whether at his or her own school or while performing a supporting role at another district school experiencing a school shooting. Additional questions regarding advocacy and support for related training or professional development would also prove beneficial.

Moreover, school counselors ought to review the referral process with their contracted, school-based mental health professionals (or known community therapists working with students). By doing so, they can ensure that all parents are made aware of and are given the opportunity to approve information sharing between the school counselor and school-based mental health professional at the time of becoming a client of the schoolbased mental health professional. In the context of culturally diverse student and parent populations, school counselors would be wise to consider the role that culture plays in parental beliefs and attitudes toward the 
counseling or helping profession when discussing counseling matters with parents. For example, parents may not want it known that their children are receiving counseling. Consequently, school counselors may need to take extra care to discuss confidentiality as it pertains to an "information-sharing" system. With an information-sharing system in place, schedules may be developed between the school counselor and schoolbased mental health professional to review general information about current caseloads of students at the school and to develop safety plans for student-clients who appear to need them.

Activating this phase is aligned with the School Counselor Competencies of the ASCA National Model. This phase of the framework recommends self-assessment, understanding expectations during a school shooting crisis, and the significance of communicating and collaborating with other mental health professionals in the referral process. These recommendations are evident in the following ASCA (2019) school counselor competencies:

- B-PF 2.c. Explain and/or inform the process for development of policy and procedures at the building, district, state and national levels.

- B-PF 6.f. Understand personal limitations and biases, and articulate how they may affect the school counselor's work.

- B-PF 7.a. Identify sources of power and authority and formal and informal leadership.

- B-SS 4.b. Communicate the limits of school counseling and the continuum of mental health services. (pp. 96-99)

As with the pre-preparation phase, school counselors would benefit from considering the developmental level and the cultural climate of their building's population. For example, the expectations of school counselors during school shooting crises may differ depending on the age of the students served, as well as the number of faculty or the staff-to-student ratio. Recommendations for this phase are aligned with the MSCS cultural competence area multicultural family counseling, as school counselors are encouraged to consider the cultural appropriateness of their counseling and/or helping style, particularly during the referral process (HolcombMcCoy, 2004).

\section{In-Crisis Protocol: Description and Activation}

The in-crisis protocol phase is also aligned with the foundational theories. The theories claim that a school shooting is a situational crisis that takes place before, during, and after the violent tragedy. The in-crisis sections highlight the major areas that are critical for school counselors during such crises. In this phase, the author discusses critical decision points not only in collaboration with the school crisis team, but also with building-level administrators. School counselors may review possible scenarios to help determine decision points. Afterward, school counselors, in collaboration with administrators and crisis planning team members, can include these decisions in the plan. One way to do this is to create decision-making trees (see Figure 1). 


\section{Figure 1}

Example of a Decision-Making Tree for a Person Experiencing a Violent Crisis (Brown, 2017)

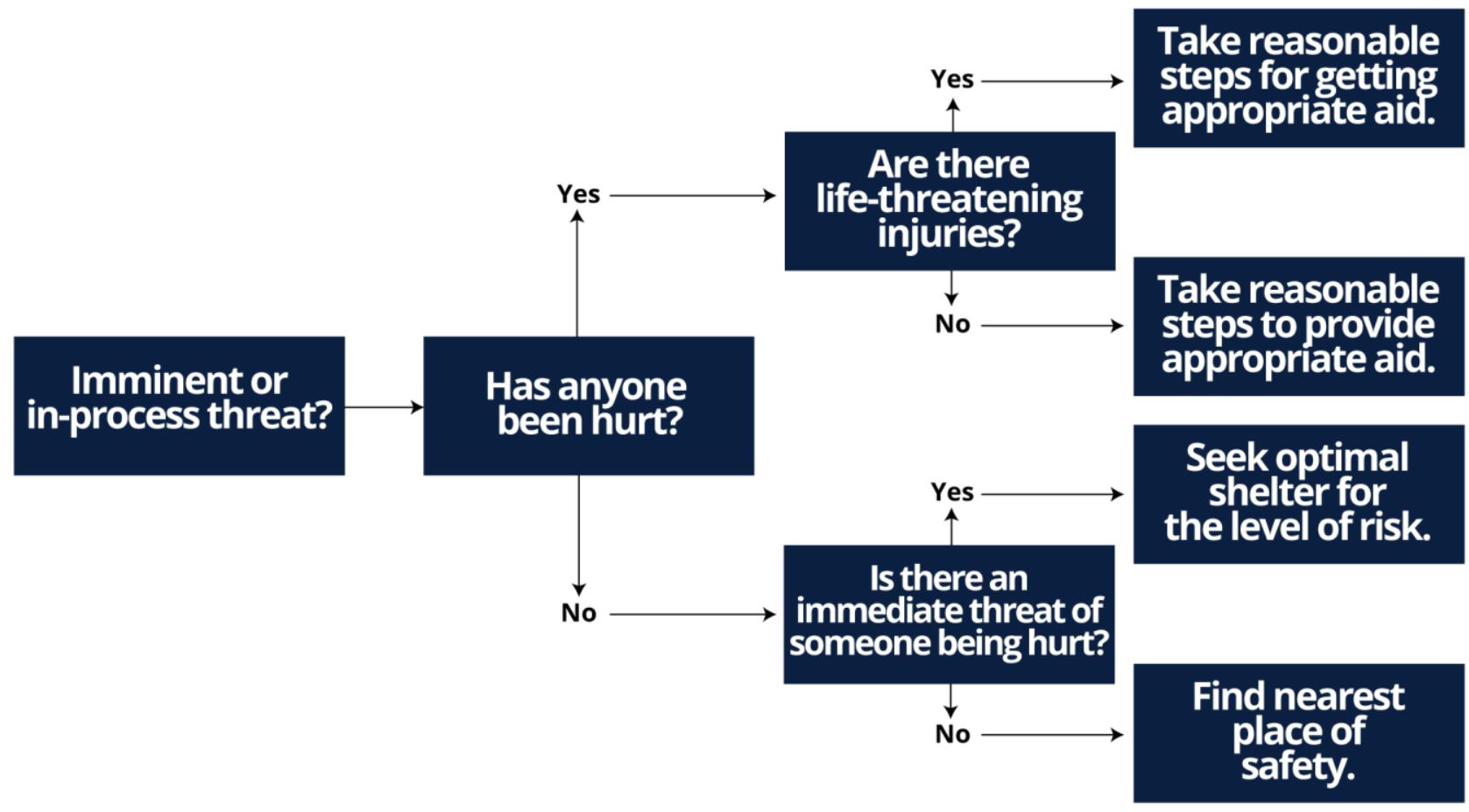

Furthermore, school counselors who have family members attending the same school or district will need to discuss a safety plan with their family members in case the school counselor finds him- or herself in conflict as a result of needing to help students while being concerned about said family members. Ideas for this safety plan might include specifying who to contact in advance, friends or adults with whom it is safe to go home, and so forth. Lastly, school counselors should advocate for training to cover de-stressing techniques when working with diverse populations who are experiencing a crisis. Examples of such training might include debriefing, mindfulness, self-compassion techniques, muscle relaxation methods, mental imagery, deep breathing techniques, and cognitive behavioral strategies.

Activating this phase of the framework is aligned with the School Counselor Competencies of the ASCA National Model, as school counselors are encouraged to collaborate with stakeholders in planning for in-crisis situations, encourage planning for family members, and advocate for training to improve crisis-counseling skills. These ideas are aligned with the following ASCA (2019) school counselor competencies:

- B-SS 3.e. Respond with appropriate intervention strategies to meet the needs of the individual, group or school community... during... crisis response.

- B-SS 5.c. Consult with school counselors and other education and counseling professionals when questions of school counseling practice arise.

- B-SS 6.c. Identify and involve appropriate school and community professionals as well as the family in a crisis situation. (pp. 99-100)

This phase is also aligned with the MCSC competency area of social advocacy; as part of crisis-counseling training, school counselors would need to consider professional development that addresses the mental and 
social issues such a tragedy may have on a diverse student population's development (Holcomb-McCoy, 2004).

\section{In-Crisis Awareness: Description and Activation}

In conjunction with the in-crisis protocol phase, it benefits school counselors to assess professional barriers to their ability to assist others during a crisis. The in-crisis awareness phase draws attention to counselors' selfcare as well as to their professional competency. School counselors may activate this phase by practicing and reviewing de-stressing techniques for the self and not just for others, thus becoming familiar with stressrelieving practices that are suitable for them such as self-coping strategies, emotional-regulation skills, selftalk, self-compassion, grounding, and paradoxical relaxation. These practices are critical for school counselors who are working through their own crisis-driven anxieties while attempting to help others. In addition, school counselors should be aware of the limits of their expertise or competencies in working through a crisis situation with others. For example, a school counselor should not attempt to implement crisis-counseling strategies in which he or she has not been trained or is not experienced. Examples might include performing psychological first aid and desensitization techniques.

To activate this phase, school counselors are encouraged to have a reflective professional development plan. This idea is aligned with the ASCA (2019) school counselor competency B-PF 4.d: "Develop a yearly professional development plan to ensure engagement in professional growth opportunities related to relevant professional standards and competencies and personal limitations" (p. 97).

In this phase, it is suggested that appropriate crisis training includes not only de-stressing and self-coping techniques but also the ability to determine that counseling strategies are culturally and developmentally appropriate for the population served. This notion coincides with the multicultural counseling area of the MCSC (Holcomb-McCoy, 2004, p. 179).

\section{Post-Crisis Response: Description}

The post-crisis response phase is also based in theory, primarily on the hypothesis that a school shooting continues to unfold after the end of the situational crisis. This phase recommends that school counselors pay attention to trained resources, readily available resources, roles and expectations, and strategies and interventions. The activation of this phase includes collecting and developing appropriate resources and materials and assisting in planning the coordination of mental health procedures and support. Appropriate resources may include being a trained resource in psychological triage, having a pre-screened list of community mental health helpers, short- and long-term trauma educational materials, and basic life functioning assistance. Lastly, it would benefit school counselors to create a professional toolkit or list of possible culturally sensitive counseling skills, strategies, and interventions to use with any crisis survivor in the immediate aftermath of a school shooting and in the long term thereafter.

To activate this phase, school counselors must be adept at coordinating and collaborating with other mental health professionals, as well as at identifying and conducting crisis response counseling and interventions. These skills are aligned with the following ASCA (2019) school counselor competencies:

- B-PF 6.a. Demonstrate basic knowledge and respect of differences in customs, communications, traditions, values and other traits among students based on race, religion, ethnicity, nationality, sexual orientation, gender identity, physical or intellectual ability and other factors.

- B-SS 3.b. Provide support for students, including individual and small-group counseling, during times of transition, heightened stress, critical change or other situations impeding student success. 
- B-SS 3.d. Explain the impact of adverse childhood experiences and trauma, and demonstrate techniques to support students who have experienced trauma.

- B-SS 4.a. Maintain a list of current referral resources, consistent with school and district policies, for students, staff and families to effectively address... social/emotional issues. (pp. 97-99)

This phase is also aligned with the MCSC's "developing school-family-community partnerships" and "multicultural counseling," as school counselors work with community volunteers and are prepared to provide training to culturally diverse populations (Holcomb-McCoy, 2004, p. 180).

\section{PoCA: Description}

Alongside the post-crisis response phase, school counselors benefit from assessing the challenges they may face in recovery efforts after such a crisis. In the PoCA phase, school counselors should consider the notions of long-term care and personal care or support. In order to activate the PoCA phase, school counselors may take steps to address both crisis survivors and themselves. Five steps are involved when considering crisis survivors. First, counselors must be prepared to consider screened volunteer counselors' specific specialties when referring, discussing, or matching parents and students with counselors. Second, counselors must be prepared to address the stigma of counseling. Third, finances must be taken into consideration; will agencies be willing to offer free counseling to crisis survivors? If so, for how long? Fourth, counselors must plan to continue educating crisis survivors about the long-term impact(s) of such a crisis. Fifth, they must offer extended counseling services to students in need and measure the efficacy of the strategies and interventions offered to ascertain the degree to which and length of time for which services should continue. In terms of the self, the following are important:

a. being willing to participate in debriefing sessions,

b. seeking mental health services (consider, for example, identifying mental health professionals in counselors' current communities who would be a good fit for them),

c. giving thought to those on whom counselors might turn for peer support, consultation, and supervision,

d. being mindful not to spend the majority of their time in isolation, and

e. developing a comprehensive self-care plan.

With its focus on working with community agencies, intervention strategies, personal reflection, and consultation, this phase is aligned with the following ASCA (2019) school counselor competencies:

- B-PF 4.c. Use personal reflection, consultation and supervision to promote professional growth and development.

- B-SS 3.e. Respond with appropriate intervention strategies to meet the needs of the individual, group or school community... after crisis response.

- B-SS 4. Make referrals to appropriate school and community resources. (pp. 97-99) 
This phase reflects the "multicultural consultation" and the "developing school-family-community partnerships" areas of the MCSC, as school counselors consult and use their skills to work with diverse community and family stakeholders (Holcomb-McCoy, 2004, pp. 179-180).

\section{ASCA National Model}

The Define, Manage, Deliver and Assess sections of the ASCA National Model (2019) align with the SCRSSFR, which is sequential in three broad areas: before (pre-phases), during (in-phases), and after (post-phases). The pre-phases (pre-preparation and pre-awareness) align with the Define (or Foundation) and Manage sections. The Define section includes the school counselor's professional competencies, which have been outlined in each phase of the activation section above. In the Manage section, school counselors are encouraged to be reflective of the needs of their school and their students. School counselors and their supervisors are encouraged to begin a process of reflection and planning in preparation for a school shooting tragedy via the pre-phases of the SCRSS-FR.

The in-phases (in-protocol and in-awareness) are aligned with the Deliver section, which states that school counselors are engaged actively in both direct and indirect services. The SCRSS-FR advises school counselors to become equipped to deliver services to their building's population and to themselves during a crisis.

The post-phases (post-protocol and post-awareness) are aligned with the Deliver and Assess sections. The Deliver section is specific to services to and on behalf of students, while the Assess section asks school counselors to take stock of the effectiveness of their programs. The SCRSS-FR promotes readiness to provide services in the aftermath of a school shooting among school counselors but also advocates keeping track of resources, materials, and counseling services over time, as well as supporting evaluations of the effectiveness of school counselors' own strategies and the interventions offered through their school counseling programs.

\section{Summary and Recommendations}

The aim of this framework of recommendations is to elicit research-informed practices from school counselors who have experienced school shootings, as well as from federal guidelines, relevant research, and professional literature. These efforts add to the much-needed current literature and provide a more comprehensive set of recommendations for effective ways school counselors can prepare for and respond to school shootings. The author used theory-building concepts and produced a conceptual framework, the School Counselor Response to School Shootings framework of recommendations (SCRSS-FR), to assist in guiding school counselors in their preparation for and response to a school shooting. The framework of recommendations offers informed and beneficial measures that school counselors can take in preparation for crisis, responding in-crisis, and for post-crisis recovery.

The framework of recommendations benefits school counselors, crisis teams, response planners, researchers, counselor educators, and formal administrators. It is intended to serve as a support tool for school crisis planning to provide help in guiding crisis planners to identify effective ways of using school counselors' expertise in crisis situations. School officials, practitioners, and counselor educators may use the framework of recommendations in the provision of crisis management education. The framework of recommendations can serve as a helpful checklist of phases in workshops or educational sessions. The author suggests that, when educating others using the framework of recommendations, facilitators offer trainees the opportunity to assess their needs via the framework of recommendations, provide opportunities for discussion, and rehearse skills where applicable. Furthermore, supervisors of school counselors may use the framework of recommendations to assess school counselors' limitations in terms of crisis preparation and response. Both 
supervisors and school counselors may use the framework of recommendations as a guide throughout such a crisis.

Because the framework is aligned with ASCA ethics, standards, and competencies, ASCA and state school counseling associations may use the framework to assist their members to define their roles and skills when preparing for and responding to a school shooting.

The framework of recommendations is a guide or tool and does not purport to be a comprehensive solution for preventing and responding to a school shooting. The framework of recommendations promotes effective practices and lessons learned from school counselors who have experienced school shootings. Unfortunately, despite the many preventive efforts, the occurrence of further school shootings remains possible in our nation. As researchers attempt to remain up to date with these tragedies, best practices and the implementation of those practices may require modification. Consequently, the SCRSS-FR, although grounded in current research, may need to be refined in the future.

Researchers may find it useful to offer comparative case studies using novel school shootings. The SCRSS-FR may be used in research as an analytical strategy or theoretical proposition to facilitate the interpretation of data from their case studies (Yin, 2009). Researchers may find it beneficial to pursue further research on effective technical skills to employ throughout a school shooting. Moreover, researchers may produce instruments or surveys based on the framework to generalize their findings across various settings. Finally, researchers may study the use of the SCRSS-FR to refine our understanding of school counselors' roles and effectiveness throughout such events on an on-going basis. 


\section{References}

Ahmed, S., \& Walker, C. (2018, May 25). There has been, on average, 1 school shooting every week this year. CNN. https://www.cnn.com/2018/03/02/us/school-shootings-2018-list-trnd/index.html

American School Counselor Association (n.d.). Helping kids during crisis. https://www.schoolcounselor.org/school-counselors/professional-development/learn-more/helpingkids-during-crisis

American School Counselor Association (2012). ASCA national model: A framework for school counseling programs (3rd ed.). Author.

American School Counselor Association (2013). Position statement: The professional school counselor and safe schools and crisis response. http://www.schoolcounselor.org/school-counselorsmembers/about-asca-(1)/position-statements.

American School Counselor Association (2016a). ASCA ethical standards for school counselors. https://www.schoolcounselor.org/asca/media/asca/Ethics/EthicalStandards2016.pdf.

American School Counselor Association (2016b). Position statement: The school counselor and the promotion of safe schools through conflict resolution and bullying/harassment prevention. https://www.schoolcounselor.org/school-counselors-members/publications/position-statements.

American School Counselor Association (2018). Position statement: The school counselor and gun safety in schools. https://www.schoolcounselor.org/school-counselors-members/publications/positionstatements

American School Counselor Association (2019). ASCA national model: A framework for school counseling programs (4th ed.). Author.

Austin, S. J. (2003). Lessons learned from the shootings at Columbine High School. https://www.schoolcounselor.org/asca/media/asca/Crisis/columbine.pdf.

Baker, S. B., \& Gerler, E. R., Jr. (2008). School counseling for the 21st century (5th ed.). Pearson Education, Inc.

Barton, E. A. (2009). Leadership strategies for safe schools. Corwin.

Bellisle, M. (2013, October 27). In wake of Nev. shooting, police review school safety. USA Today. http://www.usatoday.com/story/news/nation/2013/10/27/nevada-school-shooting-policereview/3281441/

Blair, J. P., \& Schweit, K. W. (2014). A study of active shooter incidents, 200o-2013. Texas State University and Federal Bureau of Investigation, U.S. Department of Justice, Washington DC. https://www.fbi.gov/file-repository/active-shooter-study-2000-2013-1.pdf/view

Bockler, Seeger, Sitzer, \& Heitmeyer (2013). School shootings: International research, case studies, and concepts for prevention. Springer.

Bolnick, L., \& Brock, S. E. (2005). The self-reported effects of crisis intervention work on school psychologists. The California School Psychologists 10(1), 117-124. http://citeseerx.ist.psu.edu/viewdoc/download?doi=10.1.1.485.6749\&rep=rep1\&type=pdf

Brammer (1973). The Helping Relationship: Process and Skills. Prentice-Hall, Inc.

Brammer (1979). The Helping Relationship: Process and Skills (2nd ed.). Prentice-Hall, Inc.

Brock, S. E., \& Jimerson, S. R. (2004). School crisis interventions: Strategies for addressing the consequences of crisis events. In E. R. Gerler Jr. (Ed.), Handbook of school violence (pp. 285-332). Haworth Press. 
Brock, S. E., Nickerson, A. B., Reeves, M. A., Conolly, C. N., Jimerson, S. R., Pesce, R. C., \& Lazzaro, B. R. (2016). School crisis prevention and intervention: The PREPaRE model (2nd ed.). National Association of School Psychologists.

Brock, S. E., Nickerson, A. B., Reeves, M. A., Jimerson, S. R., Lieberman, R., \& Feinberg, T. (2009). School crisis prevention and intervention: The PREPaRE model. National Association of School Psychologists.

Brown, C. H. (2015). School counselors lived experience of a rampage school shooting. (Publication No. 1728871610). [Doctoral dissertation, University of Arkansas-Fayetteville.] ProQuest Dissertations \& Theses Global.

Brown, C. H. (2017). The role of leadership in surviving a school shooting. Journal of Cases in Educational Leadership, 21(2), 3-14. https://doi.org/10.1177/1555458917735357.

Brown, C. H. (2019). Perceptions of school counselors surviving a school shooting. Professional School Counseling, 22(1), 1-13. https://doi.org/10.1177/2156759X19853250.

Chuck, E., Johnson, A., \& Siemaszko C. (2018, February 15). 17 killed in mass shooting at high school in Parkland, Florida. NBC News. https://www.nbcnews.com/news/us-news/police-respond-shootingparkland-florida-high-school-n848101.

Collins, B. G., \& Collins, T. M. (2005). Crisis and trauma: Developmental-ecological intervention. Houghton Mifflin.

Cowan, K. C., Vaillancourt, K., Rossen, E., \& Pollitt, K. (2013). A framework for safe and successful schools [Brief]. National Association of School Psychologists. https://www.schoolcounselor.org/asca/media/asca/home/FrameworkforSafeandSuccessfulSchoolEn vironments.PDF

Crepeau-Hobson, F., Sievering, K. S., Armstrong, C., \& Stonis, J. (2012). A coordinated mental health crisis response: Lessons learned from three Colorado school shootings. Journal of School Violence, (11)3, 2017-225. https://doi.org/10.1080/15388220.2012.682002

Crepeau-Hobson, F., \& Summers, L. L. (2011). The crisis response to a school-based hostage event: A case study. Journal of School Violence, 1O(3), 281-298. https://doi.org/10.1080/15388220.2011.578277

Damiani, V. B. (2011). Crisis prevention and intervention in the classroom: What teachers should know. Rowman \& Littlefield Education.

D’Andrea, M. (2004). Comprehensive school-based violence training: A developmental-ecological training model. Journal of Counseling \& Development, 82(3), 277-286. https://doi.org/10.1002/j.15566678.2004.tboo311.x

Daniels, J. A., Bradley, M. C., Cramer, D. P., Winkler, A., Kinebrew, K., \& Crockett, D. (2007a). In the aftermath of a school hostage event: A case study of one school counselor's response. Professional School Counseling, $10(5), 482-489$.

Daniels, J. A., Bradley, M. C., and Hays, M. (2007b). The impact of school violence on school personnel: Implications for psychologists. Professional Psychology: Research and Practice, 38(6), 652-659. https://doi.org/10.1037/0735-7028.38.6.652

Dekovic, M., Koning, I. M., Stams, G. J., \& Buist, K. L. (2008). Factors associated with traumatic symptoms and internalizing problems among adolescents who experienced a traumatic event. Anxiety, Stress, and Coping, 21(4), 377-386. https://doi.org/10.1080/10615800701791161

DeMatthews, D., \& Brown, C. H. (2019). Urban school leadership and community violence: Principal perspectives and proactive responses to student mental health needs. The Educational Forum, 83(1), 28-43. https://doi.org/10.1080/00131725.2018.1506846. 
Dinkes, R., Kemp, J., \& Baum, K. (2009). Indicators of school crime and safety: 2008 (NCES 2009-022/NCJ 226343). National Center for Education Statistics, Institute of Education Sciences, U.S. Department of Education, and Bureau of Justice Statistics, Office of Justice Programs, U.S. Department of Justice. https://nces.ed.gov/pubs2009/2009022REV 1.pdf

Erbacher, T. A., \& Reeves, M. A. (2018). Current and future directions in school crisis response. In J. C. Roth and B. S. Fernandez (Eds.), Perspectives on school crisis response: Reflections from the field (pp. 265-278). Routledge.

Fein, A. (2003). There and back again: School shootings as experienced by school leaders. Scarecrow Press.

Fein, A. H. (2001). There and back again: A phenomenological inquiry of school shootings as experienced by school leaders (Publication No. 3010147). ProQuest Dissertations \& Theses Global.

Fein, A. H., Carlisle, C. S., \& Isaacson, N. S. (2008). School shootings and counselor leadership: Four lessons from the field. Professional School Counseling, 11(4), 246-252. https://doi.org/10.1177\%2F2156759X0801100405.

Fein, R. A., Vossekuil, B., Pollack, W. S., Borum, R., Modzeleski, W., \& Reddy, M. (2004). Threat assessment in schools: A guide to managing threatening situations and to creating safe school climates. U.S. Secret Service and U.S. Department of Education. https://www2.ed.gov/admins/lead/safety/threatassessmentguide.pdf

Fox, C., Roth, W., \& Newman, K. (2003). A deadly partnership: Lethal violence in an Arkansas middle school. In M. Moore, C. Petrie, A. Braga \& B. McLaughlin (Eds.), Deadly lessons: Understanding lethal school violence (pp. 101-131). The National Academies Press.

Fox, J. A., \& Burstein, H. (2010). Violence and security on campus: From preschool through college. Praeger.

Gil, S., \& Caspi, Y. (2006). Personality traits, coping style, and perceived threat as predictors of posttraumatic stress disorder after exposure to a terrorist attack: A prospective study. Psychosomatic Medicine, 68(6), 904-909. Doi:10.1097/01.psy0000242124.21796.f8.

Griffin, D., \& Farris, A. (2010). School counselors and collaboration: Finding resources through community asset mapping. Professional School Counseling, 13(5), 248-256. https://doi.org/10.1177/2156759X1001300501

Heaviside, S., Rowand, C., Williams, C., Farris, E., \& Westat, I. M. (1998). Violence and discipline problems in U.S. public schools: 1996-97 (NCES 98-030). U.S. Department of Education, Office of Educational Research and Improvement.

Hermann, M. A., \& Finn, A. (2002). An ethical and legal perspective on the role of school counselors in preventing violence in schools. Professional School Counseling, 6(1), 46-54. https://www.jstor.org/stable/42732389.

Holcomb-McCoy, C. (2004). Assessing the multicultural competence of school counselors: A checklist. Professional School Counseling, 7(3), 178-186. http://www.jstor.org/stable/42732560.

James, R. K. (2008). Crisis intervention strategies (6th ed.). Thomson Brooks/Cole.

Jones, C. (2019). Schools keep hiring counselors, but students'stress levels are only growing: Fires, shootings, social media are taking a toll on students' mental health, and counselors are overwhelmed. EdSource. https://edsource.org/2019/schools-keep-hiring-counselors-but-studentsstress-levels-are-only-growing/620281.

Jordan, K. (2010). Vicarious trauma: Proposed factors that impact clinicians. Journal of Family Psychotherapy, 21(4), 225-237. https://doi.org/10.1080/08975353.2010.529003. 
Kennedy-Paine, C. (2018). Hope and healing: A community response to a school shooting. In C. Roth \& B. S. Fernandez (Eds.), Perspectives on school crisis response: Reflections from the field. Routledge.

Lambert, S. F., \& Lawson, G. (2013). Resilience of professional counselors following hurricanes Katrina and Rita. Journal of Counseling and Development, 91(3), 261-268. https://doi.org/10.1002/j.15566676.2013.00094.x.

Langman, P. (2009). Why kids kill: Inside the minds of school shooters. Palgrave Macmillan.

Litz, B. T., Gray, M. J., Bryant, R. A., \& Adler, A. (2002). Early intervention for trauma: Current status and future directions. Clinical Psychology: Science and Practice, 9(2), 112-134. https://doi.org/10.1093/clipsy.9.2.112.

Lyytinen, N. \& Palonen, K. (2012). Aftercare: Support for school personnel following a shooting in Finland. In C. L. Mears (Ed.), Reclaiming school in the aftermath of trauma: Advice based on experience (pp. 135-152. Palgrave Macmillan.

McAdams, C. I. (2002). Trends in the occurrence of reactive and proactive aggression among children and adolescents: Implications for preparation and practice in child and youth care. Child \& Youth Care Forum, 31(2), 89-109. https://doi.org/10.1023/A:1015370518527.

McAdams, C. R., III. \& Keener, H. J. (2008). Preparation, action, recovery: A conceptual framework for counselor preparation and response in client crises. Journal of Counseling \& Development, 86(4), 388-398. https://doi.org/10.1002/j.1556-6678.2008.tboo526.x

Mears, C. L. (2012). Trauma comes to school. In C. L. Mears (Ed). Reclaiming school in the aftermath of trauma: Advice based on experience (pp. 1-11). Palgrave Macmillan

Myer, R. A. (2001). Assessment for crisis intervention: Triage assessment model. Brooks/Cole.

Myer, R. A., Williams, R. C., Ottens, A. J., \& Schmidt, A. E. (1992). Crisis assessment: A three-dimensional model for triage. Journal of Mental Health Counseling, 14(2), 137-148.

Meyers, T. W., \& Cornille, T. A. (2002). The trauma of working with traumatized children. In C. R. Figley (Ed.), Treating compassion fatigue (pp. 39-55). Brunner-Routledge.

Nader, K., \& Nader, W. (2012). Youth at risk: Targeted shootings, other school violence, and suicide. In Nader, K. (Ed.), School rampage shootings and other youth disturbances: Early preventive interventions (pp. 33-70). Routledge.

National Association of School Psychologists (2018). Framework for safe and successful schools: Considerations and action steps [Brief]. National Association of School Psychologists.

National Association of School Resource Officers (N.A.S.R.O.) (n.d.). Frequently asked questions: What is a school resource officer? https://www.nasro.org/faq/

National Threat Assessment Center. (2018). Enhancing school safety using a threat assessment model: An operational guide for preventing targeted school violence. U.S. Secret Service, Department of Homeland Security. https://www.cisa.gov/sites/default/files/publications/18 o711 USSS NTACEnhancing-School-Safety-Guide.pdf

Newman, K., Fox, C., Harding, D., Mehta, J., \& Roth, W. (2004). Rampage: The social roots of school shootings. Basic Books.

O’Toole, M. E. (1999). The school shooter: A threat assessment perspective. Critical Incident Response Group, National Center for the Analysis of Violent Crime, FBI Academy.

Parker, C. L., Everly, G. S., Barnett, D. J., \& Links, J. M. (2006). Establishing evidence-informed core intervention competencies in psychological first aid for public health personnel. International Journal of Emergency Mental Health, 8(2), 83-92. 
Pepper, M. J., London, T. D., Dishman, M. L., and Lewis, J. L. (2010). Leading schools during crisis: What school administrators must know. Rowman \& Littlefield Education.

Poland, S. (2018). Responding to shootings in my school district: Commitment to crisis prevention and intervention. In C. Roth \& B. S. Fernandez (Eds.), Perspectives on school crisis response: Reflections from the field. Routledge.

Rocque, M. (2012). Exploring school rampage shootings: Research, theory, and policy. The Social Science Journal, 49(3), 304-313. http://dx.doi.org/10.1016/j.soscij.2011.11.001

Skiba, R. J. (2008). Are zero tolerance policies effective in the schools? An evidentiary review and recommendations. American Psychologist, 63(9), 852-862. http://psycnet.apa.org/doi/10.1037/0003-066X.63.9.852

Skiba, R., \& Peterson, R. (1999). The dark side of zero tolerance. The Phi Delta Kappan, 80(5), 371-376, 381382. https://www.jstor.org/stable/20439450

Suomalainen, L., Haravuori, H., Berg, N. Kiviruusu, O., \& Marttunen, M. (2011). A controlled follow-up study of adolescents exposed to a school shooting-Psychology consequences after four months. European Psychiatry, 26, 490-497. https://www.sciencedirect.com/science/article/abs/pii/So924933810001513.

U.S. Department of Education, Office of Safe and Drug-Free Schools. (2007, January). Practical information on crisis planning: A guide for schools and communities. http://www2.ed.gov/admins/lead/safety/emergencyplan/crisisplanning.pdf

U.S. Department of Health and Human Services. (2004). Mental health response to mass violence and terrorism: A training manual. Center for Mental Health Services, Substance Abuse and Mental Health Services Administration.

U.S. Department of Homeland Security (2019). Active Shooter. https://www.ready.gov/active-shooter.

U.S. Department of Justice, Bureau of Justice, Assistance, \& International Association of Chiefs of Police (2012, September). Guide for preventing and responding to school violence (2nd ed.). https://bja.ojp.gov/sites/g/files/xyckuh186/files/Publications/IACP School Violence.pdf

U.S. Department of Education, Office of Elementary and Secondary Education, Office of Safe and Healthy Students (2013, June). Guide for developing high-quality school emergency operations plans. https://www.fema.gov/media-library/assets/documents/33599

Van Dreal, J. V. (2011). Assessing student threats: A handbook for implementing the Salem-Keizer system. Rowman \& Littlefield Education.

Verlinden, S., Hersen, M., \& Thomas, J. (2000). Erratum: Risk factors in school shootings. Clinical Psychology Review, 20(5), 3-56. doi:10.1016/s0272-7358(99)00055-0

Watkins Van Asselt, K., Soli, L. L., Berry, E. L. (2016). Crisis fearlessness: A call for trauma competencies in counselor education. The Journal of Individual Psychology, 72(3), 200-213. doi:10.1353/jip.2016.0017

Weinberg, R. B. (1990). Serving large numbers of adolescent victim-survivors: Group interventions following trauma at school. Professional Psychology: Research and Practice 21(4), 271-278. https://doi.org/10.1037/0735-7028.21.4.271

Williams, A. M., Helm, H. M., \& Clemens, E. V. (2012). The effect of childhood trauma, personal wellness, supervisory working alliance, and organizational factors on vicarious traumatization. Journal of Mental Health Counseling, 34(2), 133-153. https://doi.org/10.17744/mehc.34.2.j3l62k872325h583

Yin, R. K. (2009). Case study research: Design and methods (4th ed.). Sage Publications. 
Brown, 2020

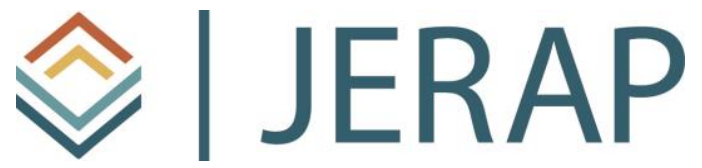

The Journal of Educational Research and Practice is a peerreviewed journal that provides a forum for studies and dialogue about developments and change in the field of education and learning. The journal includes research and related content that examine current relevant educational issues and processes. The aim is to provide readers with knowledge and with strategies to use that knowledge in educational or learning environments. JERAP focuses on education at all levels and in any setting, and includes peer-reviewed research reports, commentaries, book reviews, interviews of prominent individuals, and reports about educational practice. The journal is sponsored by the Richard W. Riley College of Education and Leadership at Walden University, and publication in JERAP is always free to authors and readers. 